\title{
EVOLUTION OF THE WAKE WAVE EXCIDED BY THE SEQUENCE OF THE RELATIVISTIC ELECTRON BUNCHES
}

\author{
O.K. Vynnyk, I.O. Anisimov \\ Taras Shevchenko National University of Kyiv, Faculty of Radio Physics, \\ Electronics and Computer Systems, Kyiv, Ukraine \\ E-mail: alexander.vynnyk@gmail.com
}

The amplitude of plasma waves, excited by the resonant sequence of electron bunches, saturates after passage of some number of bunches. This behavior was observed and simulated, using particle-in-cell code, but was not completely explained yet. Our study of this behavior was carried out via computer simulation, using modified PDP3 code - 2D3V PIC code for axially symmetric geometry and relativistic collisionless plasma. Simulation demonstrated that amplitude saturation was caused by the plasma pressing-out from the area of the most intensive wake field. This hypothesis has been verified by the obtained electrical and magnetic field spectra, temperature and density maps and density profile for various simulation times.

PACS: 29.17.+w; 41.75.Lx

\section{INTRODUCTION}

Study of the interaction of high-energy particles can be a tool for discovering so called New Physics, still unknown physics lows that could extent the Standard Model of particle physics, initially designed as temporary theoretical construction for describing of known fundamental forces and elementary particles classification. But modern methods of reaching high energies are related to large particle accelerators, which are costexpensive and takes much time to build. Plasma-based particle accelerators are very attractive alternative to modern colliders, as they can produce up to $10^{3}$ times [1] larger electrical fields comparing to traditional accelerators, with plasma wake waves, excited by particle bunches or laser pulses. It allows decreasing size of the future particle accelerators. One of the possible methods to excite high-amplitude plasma wake wave is injection of resonant sequence of particle bunches, in opposition to traditional way with single-bunch schemes. This article continues the series of scientific researches ([2 6], et al.) devoted to the study of behavior of the wake waves, excited by the sequence of the short relativistic electron bunches.

The simulation was carried out for the long sequence of short relativistic electron bunches in warm plasma $\left(T_{\mathrm{el}}=1 \mathrm{eV}, T_{\text {ions }}=0.1 \mathrm{eV}\right)$. On-axis electrical field grows close to linear law up to the saturation with further perturbation, caused by non-linear effects. It correlates with the previous simulations $([2,3,7,8])$.

\section{SIMULATION PACKAGE AND PARAMETERS SELECTION}

Simulation is carried out via PIC code, based on original PDP3 code, described in [9] and contains modifications [6], directed to improve calculation speed, concurrency, input-output and data analysis. Modernized PDP3 code implements PIC calculation algorithm in $2.5 \mathrm{D}$ cylindrical geometry as well as original one. Single-cell sized macro-particles with rectangular formfactor are axially symmetric (cylindrical rings, Fig. 1). Boris relativistic algorithm is implemented as particle advancer. Charge-conservation scheme is implemented after [10]. Maxwell equations solver is built on FDTD algorithm [11]. Perfectly matched layer [12] is used to prevent wave reflections from walls. New modifications of PDP3 code related to current article, directed to investigate temperature and plasma particles density more deeply. Original algorithms for particles temperature and density calculation, based on macro-particle parameters weighting were designed and implemented.

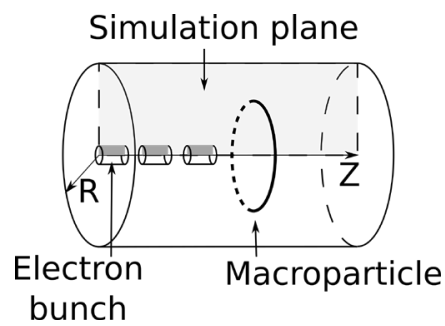

Fig. 1. General scheme of the simulation model

Simulation parameters chosen with respect to experimental conditions [4] on "Almaz-2" electron accelerator with corrections, related to plasma volume changing and fast non-linear effects occurrence.

Plasma density set to $10^{11} \mathrm{~cm}^{-3}$, bunch density $5 \times 10^{10} \mathrm{~cm}^{-3}$, bunch duration $-2 \times 10^{-11} \mathrm{~s}$. Initial bunch velocity set to $2.8 \times 10^{8} \mathrm{~m} / \mathrm{s}$, and its radius is $0.5 \mathrm{~cm}$. Simulation time is $2 \times 10^{-8} \mathrm{~s}$. Simulated plasma volume was decreased to $r=75 \mathrm{~mm}, z=600 \mathrm{~mm}$ to optimize calculation and visualization accuracy.

\section{SIMULATION RESULTS 2.1. OVERVIEW}

The simulation shows the separation by time to three serial stages at near-axis area, close to injection point (see Fig. 2). Amplitude of electrical field in plasma, caused by wake wave, grows almost linearly at initial stage (up to $5 \times 10^{-9} \mathrm{~s}$ for radial component and $7 \times 10^{-9} \mathrm{~s}$ for longitudinal component of electric field). At the measurement point, radial and longitudinal components of electric field saturate at different time moments. This behavior is probably caused by reaching highly non-linear regime and still requires further study. Initial stage finishes with the amplitude saturation. Amplitude saturation at middle simulation stage observed (Fig. 3). At the end of the middle stage amplitude decreases to neck shaped structure. Further amplitude growth with saturation at the lower amplitude (relatively to the mid- 
dle stage) is observed at the late simulation time $\left((1.5 \ldots 2) \times 10^{-8} \mathrm{~s}\right.$, after neck passage).
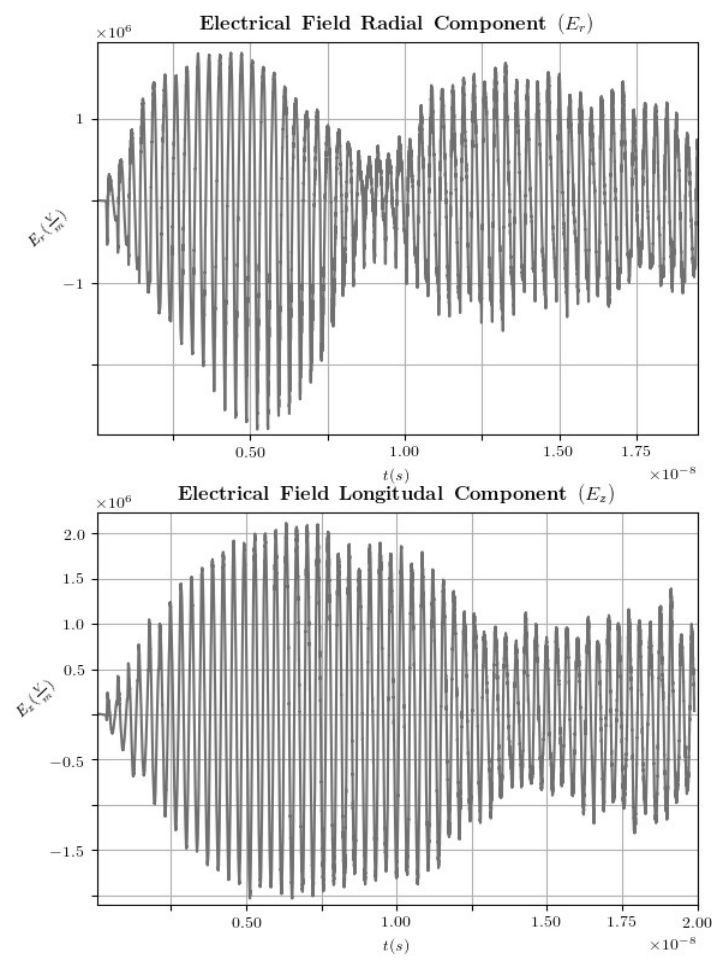

Fig. 2. Radial and longitudinal electrical field components at the point $r=0.01 \mathrm{~m}$ and $z=0.1 \mathrm{~m}$

\subsection{MECHANISMS OF THE SATURATION}

Two mechanisms are proposed as a reason for saturation with neck shaped structure: nonlinear wake field frequency shift with the further resonance breakdown or plasma density radial profile disturbance, caused by heating of the near-axis region. To verify these hypotheses, additional calculations were carried out, namely spectral analysis (including short-time Fourier transformations) and temperature and density calculating.

Classic and short-time Fourier transform of the wake field shows maximum only at the single frequency which coincide with maximum of azimuthal component of magnetic field, excited by the sequence of electron bunches and plasma frequency, calculated analytically for the initial plasma density. So, wake field frequency does not shift during the simulation time.

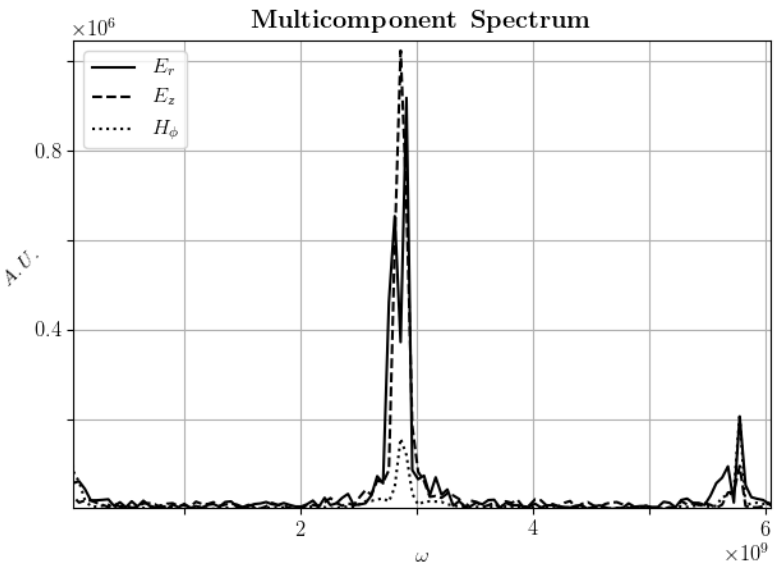

Fig. 3. Components of electrical and magnetic fields' spectra at the point $r=0.01 \mathrm{~m}, z=0.1 \mathrm{~m}$
On the other hand, temperature maps demonstrate plasma heating at the near-axis area. Plots (Fig. 4) for different time points demonstrate the ion temperature growth with time at the near-axis area along the path of electron bunches. The heating is most visible at the region of highest amplitude of plasma wake wave.

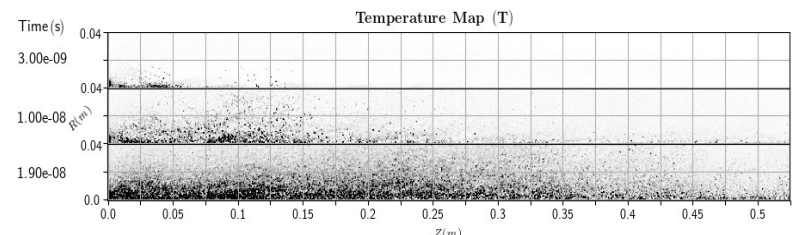

Fig. 4. Temperature map at initial $\left(3 \times 10^{-9} \mathrm{~s}\right)$, middle $\left(1 \times 10^{-8} \mathrm{~s}\right)$ and late $\left(1.9 \times 10^{-8} \mathrm{~s}\right)$ stages of simulation.

Plasma heats up at the central near-axis region (at the bottom of all plots) along the path of the sequence of electron bunches

Inhomogeneous plasma heating causes plasma pressing out from the heated regions. In this simulation it could cause disturbance of the plasma density profile in radial and longitudinal directions (see Fig. 5). Fig. 6 visualizes the density profile disturbance with time. Being initially homogenous, it grows up at the near-axis region, than decreases to the density well, than grows to the initial density value. At the late stages, density profile also makes a local density maximum right after the density well.

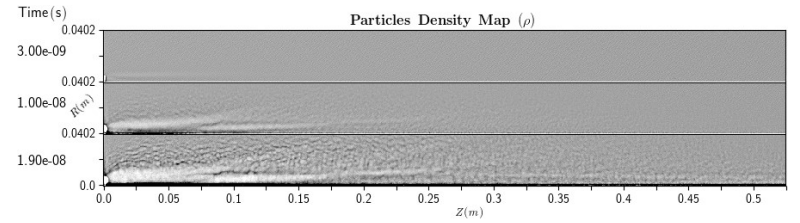

Fig. 5. Ions density map. Correlation with temperature growth (Fig. 4) observed

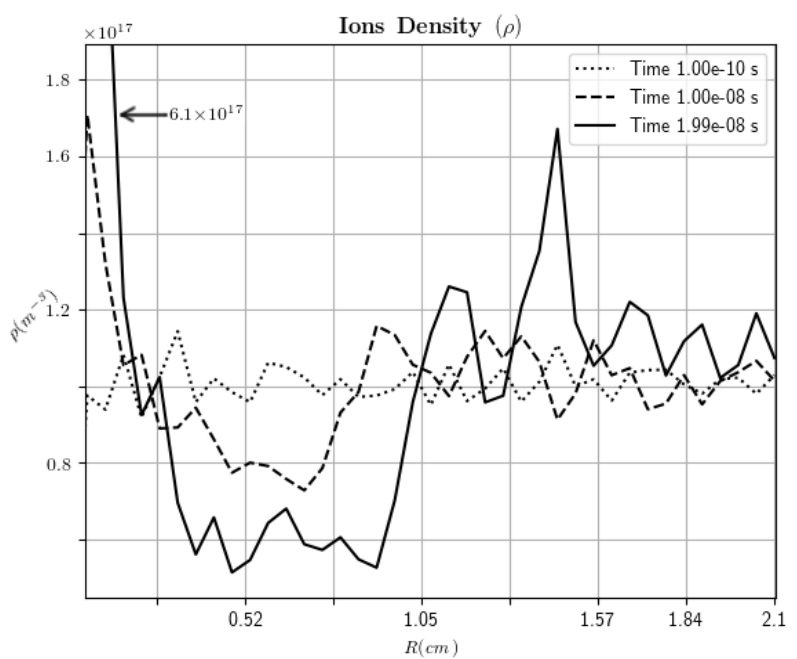

Fig. 6. Ion density radial profile at the different time points ( $z=0.1 \mathrm{~m}$ from the injection point). Density

profile disturbance is observed at the middle and late stages

Such density disturbance breaks the wave front, causing phase shift between central and peripheral parts of wake wave. Consequence of the wave front braking is the wave energy scattering and decreasing of its amplitude. On the other hand the electron bunches continuously pump the central area of plasma wave. 


\subsection{VERIFICATION USING ARTIFICIAL PLASMA PROFILE}

To verify the behavior caused by disturbance of the density profile, simulation with artificial rectangular shaped density well at the system axis was carried out. The split of wake wave front was observed in both cases (Fig. 7). Also, wake wave saturation was observed in the case of artificial density profile. The reason of some difference in the field maps of real and artificial case can be the difference in density profiles (in the real simulation it is not an ideal step) and long evolution of the real simulation model with time, starting from profile without density well.

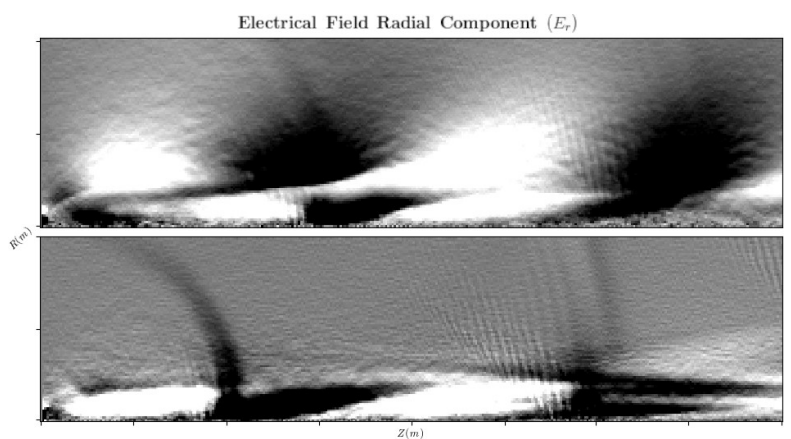

Fig. 7. Splitting wake wave front in real simulation (top) and real conditions emulation with artificial density well (bottom)

\section{CONCLUSIONS}

The simulation of saturation of the wake wave amplitude excited by the resonant sequence of the relativistic electron bunches in warm plasma was carried out. Three stages of simulation model evolution were observed: initial close to linear amplitude of wake wave growth, saturation of wake wave with further decrease to neck shaped structure, second growth with saturation at lower amplitude rate. The reason of such behavior is plasma heating at the near-axis area, which causes plasma density profile perturbation. It destroys Cherenkov resonance between the bunches' sequence and wake waves at the near-axis area. This hypothesis can be verified via preconfigured simulation with the artificial plasma density well.

\section{REFERENCES}

1. I. Blumenfeld, C.E. Clayton, F.-J. Decker, et al. Energy doubling of $42 \mathrm{GeV}$ electrons in a metrescale plasma wakefield accelerator // Nature. 2007, v. 445, № 7129, p. 741-744.

2. K.V. Lotov, V.I. Maslov, I.N. Onishchenko, I.P. Yarovaya. Transformation ratio at interaction of long sequence of electron bunches with plasma //
Problems of Atomic Science and Technology. 2008, v. 3, p. 87-91.

3. K.V. Lotov, V.I. Maslov, I.N. Onishchenko, and E.N. Svistun. 2.5D simulation of plasma wakefield excitation by a nonresonant train of relativistic electron bunches // Problems of Atomic Science and Technology. 2010, v. 2, p. 122-124.

4. V.A. Kiselev, A.F. Linnik, and V.I. Mirny. Experiments on resonator concept of plasma wakefield accelerator driven by a train of relativistic electron bunches // Problems of Atomic Science and Technology. 2008, № 4, p. 73-76.

5. K.V. Lotov. Excitation of two-dimensional plasma wake fields by trains of equidistant particle bunches // Physics of Plasmas. 2013, v. 20, № 8, p. 083119.

6. O.K. Vynnyk, I.O. Anisimov. Wake wave excited by the sequence of relativistic electron bunches: Initial stage // Problems of Atomic Science and Technology. 2018, v. 6, p. 160-163.

7. K. Lotov, V. Maslov, I. Onishchenko, E. Svistun. Simulation of plasma wakefield excitation by a sequence of relativistic electron bunches // Problems of Atomic Science and Technology. 2008, v. 6, p. 114-116.

8. V.A. Kiselev, A.F. Linnik, V.I. Mirny. Long sequence of relativistic electron bunches as a driver in wakefield method of charged particles acceleration in plasma // Problems of Atomic Science and Technology. 2010, № 6, p. 103-107.

9. Y.M. Tolochkevych, T.E. Litoshenko, I.O. Anisimov. 2.5d relativistic electromagnetic PIC code for simulation of the beam interaction with plasma in axial-symmetric geometry // Journal of Physics: Conference Series. 2014, v. 511, p. 012001.

10. J. Villasenor and O. Buneman. Rigorous charge conservation for local electromagnetic field solvers // Computer Physics Communications. 1992, v. 69, № 2, p. 306-316.

11. K. Yee. Numerical solution of initial boundary value problems involving Maxwell's equations in isotropic media // IEEE Transactions on Antennas and Propagation. 1966, v. 14, № 3, p. 302-307.

12. J.-P. Berenger. A perfectly matched layer for the absorption of electromagnetic waves // Journal of Computational Physics. 1994, v. 114, № 2, p. 185 200

Article received 27.06.2019 


\section{ЭВОЛЮЦИЯ КИЛЬВАТЕРНОЙ ВОЛНЫ, ВОЗБУЖДЕННОЙ ПОСЛЕДОВАТЕЛЬНОСТЬЮ РЕЛЯТИВИСТСКИХ ЭЛЕКТРОННЫХ СГУСТКОВ}

\section{А.К. Винник, И.А. Анисимов}

Амплитуда кильватерной волны в плазме, возбужденной резонансной последовательностью электронных сгустков, насыщается после прохождения определенного количества сгустков. Это поведение наблюдалось и было промоделировано на компьютерной модели, но пока не до конца объяснено. Проведено изучение этого поведения на компьютерной модели с использованием модифицированного PDP3 кода - 2D3V программного кода, который использует метод крупных частиц (частиц в ячейках) в аксиально-симметричной геометрии для релятивистской бесстолкновительной плазмы. Симуляция демонстрирует, что насыщение амплитуды вызвано выдавливанием плазмы из области наиболее интенсивного кильватерного поля. Эта гипотеза проверена с помощью полученных спектров компонентов электростатического и магнитного полей, а также пространственных карт температуры и концентрации плазмы, а также профилей концентрации, произведенных в разные моменты времени симуляции.

\section{ЕВОЛЮЦІЯ КІЛЬВАТЕРНОЇ ХВИЛІ, ЗБУДЖЕНОЇ ПОСЛІДОВНІСТЮ РЕЛЯТИВІСТСЬКИХ ЕЛЕКТРОННИХ ЗГУСТКІВ}

\section{О.К. Винник, І.О. Анісімов}

Амплітуда кільватерної хвилі у плазмі, збудженої резонансною послідовністю електронних згустків, насичується після проходження певної кількості згустків. Ця поведінка спостерігалася та була змодельована на комп'ютері, але ще повністю не пояснена. Наше вивчення цієї поведінки проведене на комп'ютерній моделі 3 використанням модифікованого PDP3 коду - 2D3V програмного коду, що використовує метод частинок у комірках в аксіально-симетричній геометрії та релятивістській плазмі без зіткнень. Симуляція демонструє, що насичення амплітуди викликане витисненням плазми з області найбільш інтенсивного кільватерного поля. Ця гіпотеза була перевірена за допомогою отриманих спектрів електричних та магнітних полів, а також просторових мап температури та густини плазми, а також профілів густини плазми, зроблених для різних моментів часу симуляції. 